\title{
DECREASED FERTILITY IN FEMALE MICE IMMUNIZED WITH A CARRIER FOLLOWED BY SMALL NUMBERS OF SPERMATOZOA
}

\author{
R. P. ERICKSON \\ Department of Pediatrics, University of California-San Francisco, \\ San Francisco, California 94122, U.S.A.
}

(Received 14th August 1972)

It has been conclusively shown that immunization of female mice with spermatozoa can significantly decrease their fertility (McLaren, 1964, 1966; Edwards, 1964; Bell, 1969; Bell \& McLaren, 1970). All of the work by McLaren and Bell (McLaren, 1964, 1966; Bell, 1969; Bell \& McLaren, 1970) has involved very extensive courses of immunization: from twenty-one to twenty-four injections of 6 to $15 \times 10^{6}$ spermatozoa or fractions thereof. Edwards (1964) used shorter and more varied immunization schedules, with three to eleven booster injections in different individuals of one experimental group, and found a smaller effect on the number of eggs fertilized than McLaren and Bell found on the number of liveborn offspring (McLaren, 1964, 1966; Bell, 1969; Bell \& McLaren, 1970). However, none of the female mice in Edwards experiments received fewer than $30 \times 10^{6}$ spermatozoa. This paper reports significant decreases in the fertility of female mice immunized with $15 \times 10^{6}$ spermatozoa by utilization of the carrier effect ('cooperativity').

Random-bred Swiss Webster mice were mated before sensitization and only fertile pairs were used in the experiment. A patch, 5 to $6 \mathrm{~cm}^{2}$, was shaved on the belly of the females and $0.05 \mathrm{ml}$ of $0.5 \%$ 1-fluoro-2-4-dinitrobenzene (FDNB) in a mixture of acetone and olive oil was applied three times at 10-day intervals by painting on the skin. This quantity and dosage schedule had been found to give maximal delayed hypersensitivity to dinitrophenol (DNP) in the CBA strain of mice (Taylor \& Iverson, 1971). Ten days after the last skin-painting, cultured human lymphocytes or spermatozoa from the epididymides and vasa deferentia of Swiss mice (prepared as in Erickson, 1972a) were treated with DNP by a modification of a published method (Bauminger \& Yachnin, 1972): $50 \times 10^{6}$ cells were suspended in $5 \mathrm{ml}$ phosphate-buffered saline and 2 vols of $0.05 \mathrm{M}$-EDTA, $\mathrm{pH} 8.4$ and $25 \mu \mathrm{l} 0.1 \mathrm{M}$-FDNB in acetone were added; the mixture was incubated for $15 \mathrm{~min}$ at $37^{\circ} \mathrm{C}$, and the cells were washed twice in 0.025 M-EDTA, pH 7.4, 0.075 $\mathrm{M}$-NaCl, and $0.05 \mathrm{M}$-glucose. Cells $\left(5 \times 10^{6}\right)$ per animal were injected intraperitoneally for three injections at 10-day intervals. The size and frequency of litters were recorded twice a week during and after sensitization and all newborn young were removed from the cages.

As seen in Table 1, three injections of DNP-treated spermatozoa given to DNP-skin-sensitized females decreased the litter size by about $50 \%$ whether 


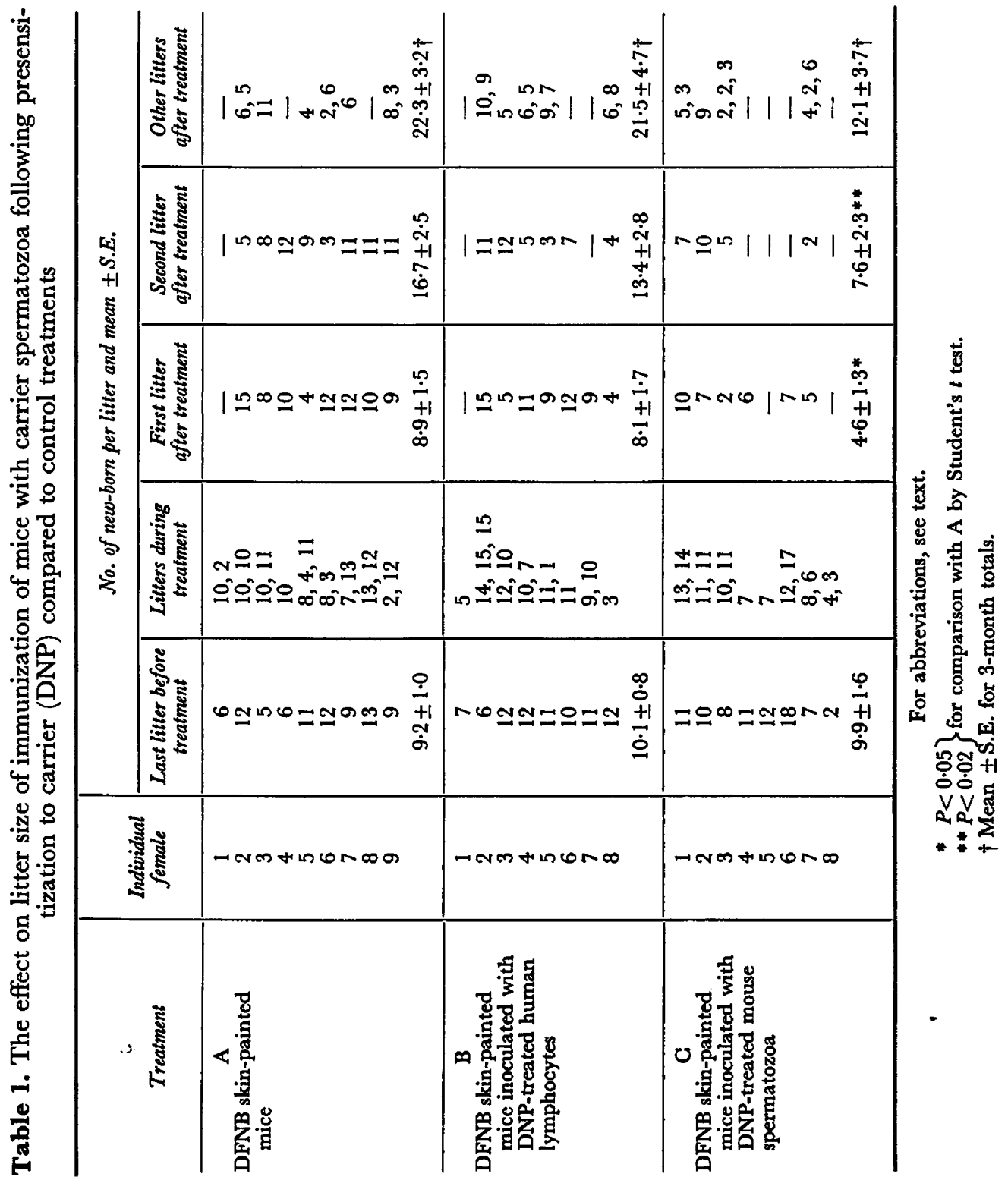


first litters, first and second litters combined, or the first 3 months of breeding after the last injection were compared. Inoculations of DNP-treated human lymphocytes had a small but insignificant effect on fertility while the DFNB skin-painting alone had a negligible effect on litter frequency and size as compared to a control period before initiation of the experiments. This decrease in fertility was comparable to the magnitude of reduction found by other investigators. Bell (1969) had a reduction in average litter size to less than half the control level when intact spermatozoa were used as the antigen but a smaller, though still highly significant, effect when sperm fractions were used as the antigens (Bell \& McLaren, 1970).

Following the 3 months of fertility testing, animals were given one booster injection of $5 \times 10^{6} \mathrm{DNP}$-treated spermatozoa or DNP-treated lymphocytes and the antibody levels in individual sera were measured by the antiglobulin test. This test uses radioactive anti- $\gamma$-globulin to determine the amount of $\gamma$-globulin

Table 2. Absorption ratios with spermatozoa for antisperm antisera raised in female mice by utilizing the carrier effect compared to one raised by multiple injections of a sperm tail fraction

\begin{tabular}{l|c|c|c|c}
\hline \multirow{2}{*}{ Antisera } & \multicolumn{4}{|c}{ Reciprocal dilutions of sera } \\
\cline { 2 - 5 } & 20 & 50 & 250 & 1000 \\
\hline $\begin{array}{l}\text { Carrier sensitization alone } \\
\text { Exemplative sera }\end{array}$ & $<1$ & 1 & 1 & 1 \\
$\begin{array}{l}\text { Carrier-raised antilymphocyte } \\
\text { Exemplative sera }\end{array}$ & $<1$ & $<1$ & $<1$ & $<1$ \\
Carrier-raised antisperm. & $<1$ & $<1$ & 1.16 & 1.07 \\
$\quad$ Serum 1 & 2.85 & $2 \cdot 7$ & 2.61 & 3.05 \\
Serum 2 & 1.3 & 1.87 & $2 \cdot 19$ & 1.45 \\
$\quad$ Serum 4 & $<1$ & $<1$ & $<1$ & 1.2 \\
Serum 5 \\
Antisperm and tail fraction & 3.4 & 4.3 & 5.1 & 4.3 \\
T-34 & & & & \\
\hline
\end{tabular}

from each antiserum absorbed on spermatozoa (Erickson, 1972b). Results are expressed as an absorption ratio, the ratio of the radioactivity absorbed to spermatozoa in the immune sera to the radioactivity absorbed to spermatozoa in normal sera. As seen in Table 2, the DNP-sensitized mice and the mice immunized with DNP-treated human lymphocytes had no antibody to mouse spermatozoa which could be detected by this test. However, two out of four sera tested from the group immunized with DNP-treated spermatozoa had significant antibody to the mouse spermatozoa and the activity of one (Serum 2) compared favourably with those found with antisperm-tail-fraction antisera raised by multiple (twenty-four) injections of antigen. High titres are characteristic of this test. Variability in measured antibody responses to spermatozoa has been well studied (McLaren, 1964, 1966; Bell, 1969). In the present experiments, the animals were pooled by groups before the boosting injection and subsequent bleeding, so correlations of antisperm and decreased fertility were not possible. 
The use of macromolecular carriers to elicit antibody against a variety of smaller chemical antigenic groups (haptens) is well known (see Landsteiner, 1962). Recent advances in the understanding of the mechanism behind the carrier effect ('cooperativity') emphasize that the interaction of two cell populations with two different antigenic determinants are probably always essential for an immune response (Mitchison, 1968; Rajewsky, Schirrmacher, Nase \& Jerne, 1969; Mitchison, Rajewsky \& Taylor, 1970). Awareness of the phenomena provides the possibility of deliberately stimulating one cell population (thymus-dependent lymphocytes, T-cells) with a carrier (DNP in this case; Mitchison, 1971) in preparation for immunization with the combination of carrier and the antigen (spermatozoa in this case) for which an immune response is desired. It is clearly established that the schedule of FDNB skinpainting used would greatly expand the population of T-cells with receptors for DNP while this 'hapten' could serve as a carrier to other antigens when coupled to the antigenic molecules. In this case, only three injections of $5 \times 10^{6}$ DNP-treated spermatozoa led to markedly decreased fertility in the presensitized mice and significant antisperm antibody levels were detected in some of the animals. It is not yet known if a qualitative change in the immune response to the spermatozoa has occurred in addition to the quantitative change.

This work was supported by a grant from the Population Council, New York. The cultured human lymphocytes were kindly provided by Dr Edward Schneider and the antisperm-tail-fraction antisera by Dr Eric Bell.

\section{REFERENCES}

BaUminger, S. \& YACHNin, S. (1972) Unimpeded growth of tumour in hosts pre-immunized with tyrosyl- or dinitrophenyl-coated tumour cells. Br. F. Cancer, 26, 77.

BELL, E. B. (1969) Immunologic control of fertility in the mouse: a comparison of systemic and intravaginal immunization. F. Reprod. Fert. 18, 183.

Bell, E. B. \& McLaren, A. (1970) Reduction of fertility in female mice iso-immunized with a subcellular sperm fraction. 7. Reprod. Fert. 22, 345.

Edwaros, R. G. (1964) Immunological control of fertility in female mice. Nature, Lond. 203, 50.

Errckson, R. P. (1972a) Alternative modes of detecting and quantification of $H \cdot 2$ antigens on sperm. In: Proc. Int. Symp. on The Genetics of the Spermatozoon, p. 191. Eds. R. A. Beatty, and S. Waelsch. Edinburgh.

ERICKson, R. P. (1972b) An antiglobulin test for the detection of surface antigens of mouse spermatozoa. F. Reprod. Fert. 28, 109.

LANDSTEINER, K. (1962) The specificity of serological reactions, pp. 101-113, 156-207. Dover, New York.

MaLAREN, A. (1964) Immunological control of fertility in female mice. Nature, Lond. 201, 582.

MaLAREN, A. (1966) Studies on the isoimmunization of mice with spermatozoa. Fert. Steril. 17, 492.

Mrtchison, N. A. (1968) Recognition of antigen. In: Symp. Int. Soc. Cell Biol. Vol. 7, 29. Differentiation and Immunology. Ed. K. B. Warren. Academic Press, New York.

Mrtchison, N. A. (1971) The carrier effect in the secondary response to hapten-protein conjugates. V. Use of antilymphocyte serum to deplete animals of helper cells. Eur. F. Immun. 1, 68.

Mrrchison, N. A., RAJEWSKy, K. \& TAYzoR, R. B. (1970) Cooperation of antigen determinants and of cells in the induction of antibodies. In: Prague Symp. on Developmental Aspects of Antibody Formation and Structure, Vol. 2, p. 547. Eds. J. Sterzl, and I. Riha. Publishing House of the Czechoslovak Academy of Sciences, Prague.

Rajewsky, K., Schirrmacher, V., Nase, S. \& Jerne, N. K. (1969) The requirement of more than one antigenic determinant for immunogenicity. F. exp. Med. 129, 1131.

Taylor, R. B. \& Iverson, G. M. (1971) Hapten competition and the nature of cell-cooperation in the antibody response. Proc. $R$. Soc. B, 176, 393. 